\title{
PENGETAHUAN DAN KESIAPSIAGAAN MASYARAKAT TERHADAP BENCANA BANJIR DI KOTA BEKASI (STUDI KASUS: PERUMAHAN PONDOK GEDE PERMAI)
}

\section{KNOWLEDGE AND COMMUNITY PREPAREDNESS TOWARD FLOOD DISASTER IN BEKASI CITY (CASE STUDY: PONDOK GEDE PERMAI RESIDENTIAL)}

\author{
Novian Andri Akhirianto \\ Pusat Teknologi Reduksi Risiko Bencana, Badan Pengkajian dan Penerapan Teknologi \\ Gedung 820, Geostech, Kawasan Puspiptek, Kota Tangerang Selatan \\ e-mail: novian.andri@bppt.go.id
}

\begin{abstract}
Flood disaster is a natural disaster that often happens in Indonesia, this data taken from $B N P B$. In 2016 flood recorded as many as 766 incidents with 147 people died. Knowledge and community preparedness are needed to avoid deadly floods disaster. Based on the results of case study research at Pondok Gede Permai Residential Bekasi City, using mixed method combining qualitative and quantitative approaches it is known that the level of community knowledge related to flood disaster is enough. One of the contributing factors is the community has a lot of experience related to flood disaster. Community preparedness that still need to be improved is on the mobilization of household resources that are still low, with indicators of community participation in flood preparedness activities are still very low.
\end{abstract}

Keywords: Flood Disaster, Knowledge,Community Preparedness, Case Study

\begin{abstract}
ABSTRAK
Bencana banjir merupakan bencana alam yang sering terjadi di Indonesia, hal tersebut dapat dilihat berdasarkan data dari BNPB. Pada tahun 2016 banjir tercatat sebanyak 766 kejadian dengan 147 jiwa meninggal dunia. Pengetahuan dan kesiapsiagaan masyarakat sangat diperlukan untuk menghadapi bencana banjir yang mematikan. Berdasarkan hasil penelitian studi kasus di Perumahan Pondok Gede Permai - Kota Bekasi, dengan metode campuran (Mixed Method) memadukan pendekatan kualitatif dan kuantitatif diketahui bahwa tingkat pengetahuan masyarakat terkait bencana banjir sudah cukup baik. Salah satu faktor penyebabnya adalah karena masyarakat memiliki pengalaman yang cukup banyak dalam menghadapi bencana banjir. Kesiapsiagaan masyarakat yang masih perlu ditingkatkan adalah mengenai mobilisasi sumberdaya rumah tangga yang masih rendah, dengan indikator keikutsertaan masyarakat dalam kegiatan kesiapsiagaan menghadapi bencana banjir masih sangat sedikit.
\end{abstract}

Katakunci: Bencana Banjir, Pengetahuan, Kesiapsiagaan Masyarakat, Studi Kasus

\section{PENDAHULUAN}

Banjir merupakan bencana alam yang perlu mendapat perhatian, karena mengancam jiwa dan ekonomi masyarakat dan merupakan bencana alam yang ke tiga terbesar di dunia yang telah banyak menelan korban jiwa dan kerugian harta benda (Aryono, 2011). Begitu juga fenomena yang terjadi di Indonesia, berdasarkan data dari Badan Nasional Penanggulangan Bencana (BNPB) yang menunjukan bahwa pada tahun 2016 bencana yang terjadi di Indonesia terbanyak adalah bencana hidrometeorologi yang didominasi oleh banjir, longsor dan puting 
beliung. Hal tersebut dapat dilihat pada Tabel 1 berikut ini.

Tabel 1. Data Kejadian Bencana di Indonesia Tahun 2016

\begin{tabular}{|l|l|c|}
\hline No & \multicolumn{1}{|c|}{ Jenis Bencana } & Jumlah Kejadian \\
\hline 1 & Banjir & 766 \\
\hline 2 & Puting Beliung & 669 \\
\hline 3 & Longsor & 612 \\
\hline 4 & $\begin{array}{l}\text { Kebakaran Hutan } \\
\text { dan Lahan }\end{array}$ & 178 \\
\hline 5 & $\begin{array}{l}\text { Kombinasi Banjir } \\
\text { dan Longsor }\end{array}$ & 74 \\
\hline 6 & $\begin{array}{l}\text { Gelombang Pasang } \\
\text { dan Abrasi }\end{array}$ & 23 \\
\hline 7 & Gempabumi & 13 \\
\hline 8 & Gunung Meletus & 7 \\
\hline
\end{tabular}

Sumber: http://dibi.bnpb.go.id
Berdasarkan data tahun 2016 bencana banjir di Indonesia merupakan bencana yang paling banyak kejadiannya, yaitu sebanyak 766 kejadian. Adapun dampak yang ditimbulkan yaitu 147 jiwa meninggal dunia, 107 jiwa luka 2,72 juta jiwa mengungsi dan menderita, dan 30.669

rumah mengalami kerusakan (www.bbc.com/indonesia, diakses 20 Desember 2017).

Kota Bekasi terletak pada tiga Daerah Aliran Sungai (DAS) utama, yaitu DAS Sunter, DAS Cakung, dan DAS Bekasi. Kali Bekasi diprediksi memiliki kontribusi besar terhadap kemungkinan terjadinya daerah-daerah rawan genangan dan banjir di wilayah yang dilintasinya. Selain itu, perkembangan di Kota Bekasi identik dengan pembangunan yang menyebabkan semakin sedikit lahan terbuka hijau dan membuat Kota Bekasi rawan terhadap bencana banjir (Bappeda Kota Bekasi, 2017).

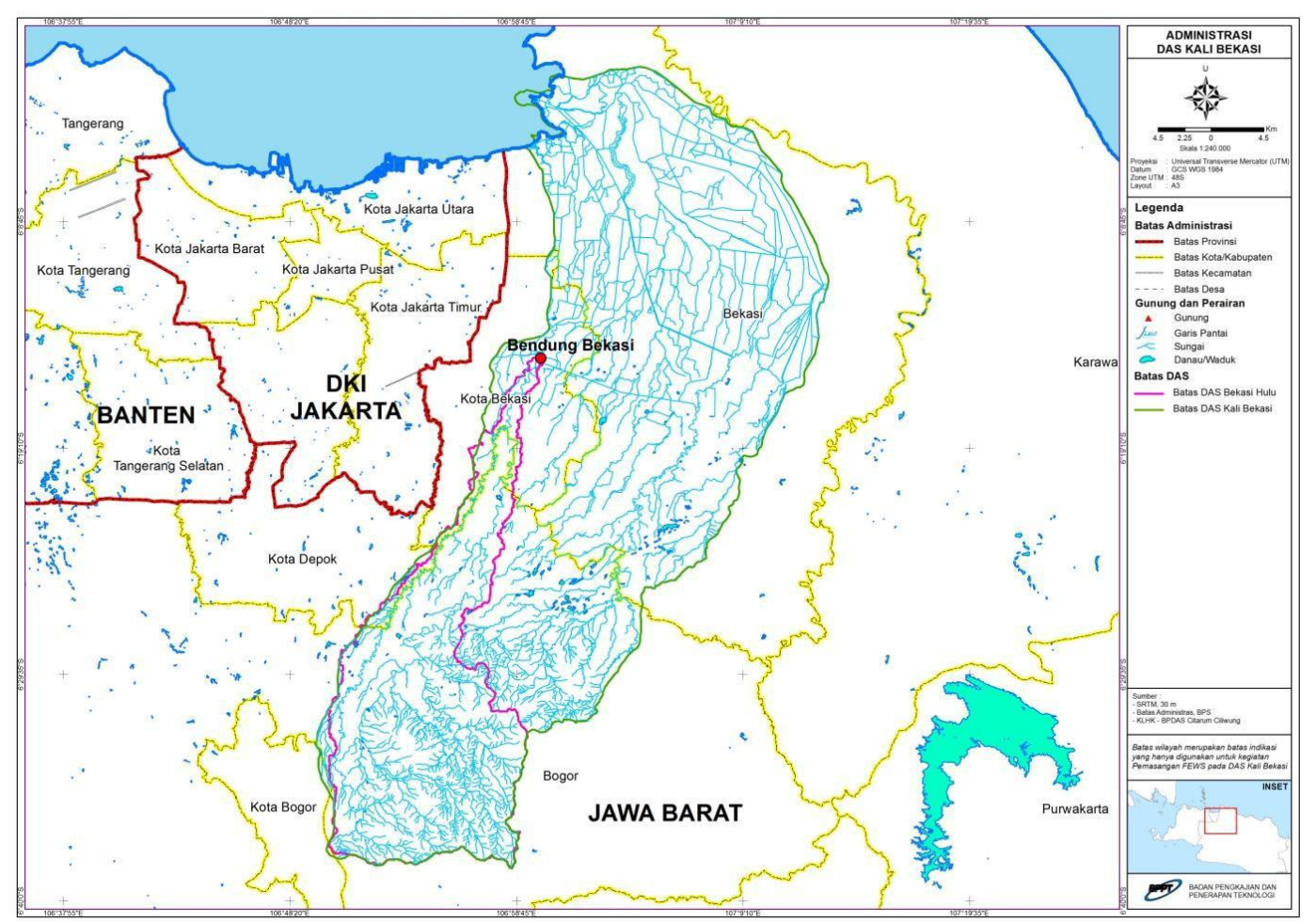

Gambar 1. Daerah Aliran Sungai Bekasi (Sumber: BPPT, 2017)

Masyarakat wajib berperan serta untuk bersiap sedia menghadapi ancaman bahaya banjir dengan persiapan dini, serta pengetahuan yang cukup untuk menghadapi bencana banjir. Kesiapsiagaan dalam menghadapi bencana banjir akan membantu masyarakat dalam membentuk dan merencanakan tindakan apa saja yang perlu dilakukan ketika banjir. Kesuksesan dalam penanganan dan evakuasi/ pengungsian ketika banjir sangat bergantung dari kesiapsiagaan masyarakat dan perseorangan itu sendiri. Kualitas terganggunya aspek kehidupan masyarakat sangatlah bergantung kepada besar kecilnya ancaman (hazard) bencana tersebut, juga dipengaruhi oleh kapasitas (capacity) masyarakat yang ada serta kerentanan (vulnerability) (Daryono, 2010).

Adapun tujuan dari penelitian ini adalah untuk memperoleh gambaran pengetahuan dan kesiapsiagaan masyarakat dalam menghadapi bencana banjir di Kota Bekasi, dengan studi kasus di Perumahan Pondok Gede Permai - 
Kota Bekasi. Dengan perpaduan pendekatan kualitatif dan kuantitatif, sehingga dapat memperluas informasi persepsi responden dan informasi yang diperoleh dapat terukur. Adapun indikator-indikator yang ingin diteliti antara lain:

a. Karakteristik demografi wilayah dan profil responden.

b. Pengetahuan dan tindakan masyarakat terkait banjir.

c. Rencana keluarga untuk merespons kondisi darurat dan mengantisipasi banjir.

d. Peringatan/ deteksi dini banjir.

e. Mobilisasi sumberdaya rumah tangga.

\section{METODE PENELITIAN}

Penelitian ini merupakan bentuk penelitian studi kasus, dengan mengambil sampel warga perumahan Pondok Gede Permai - Kota Bekasi. Studi kasus adalah penelitian tentang status subjek penelitian yang berkenan dengan suatu fase spesifik atau khas dari keseluruhan personalitas, dengan subjek penelitian dapat saja individu, kelompok, lembaga, maupun masyarakat (Nazir, 1983).

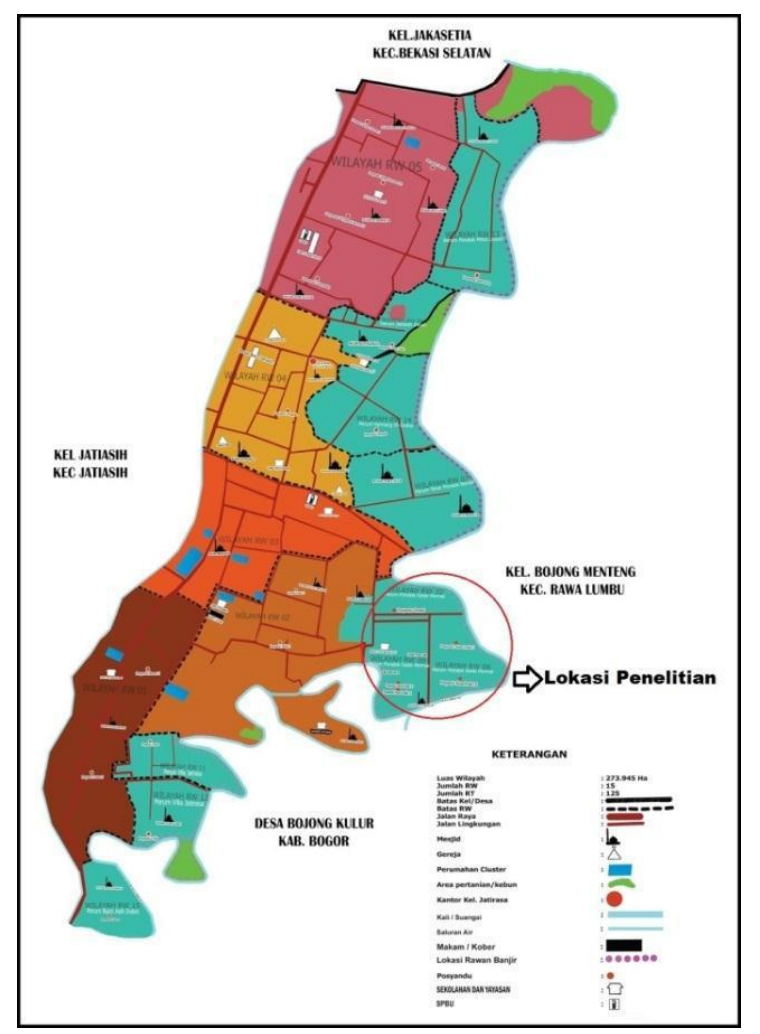

Gambar 2. Peta Lokasi Penelitian di Perum Pondok Gede Permai

Dipilihnya warga perumahan Pondok Gede Permai - Kota Bekasi sebagai sampel dalam penelitian ini karena berdasarkan hasil asesmen awal yang dilakukan ke BPBD Kota Bekasi,
Kantor Kecamatan Jatiasih dan Kantor Kelurahan Jatirasa diperoleh informasi bahwa di lokasi tersebut merupakan tempat yang mempunyai historis kejadian banjir cukup parah di Kota Bekasi. Kejadian banjir yang terparah adalah yang terjadi pada tanggal 21 April 2016, dengan ketinggian banjir di pemukiman warga mencapai 3,5 - 4 meter. Alasan lainnya adalah karena di lokasi tersebut merupakan tempat dipasangnya alat pengukur tinggi genangan, yang dilakukan oleh Pusat Teknologi Reduksi Resiko Bencana BPPT.

Penelitian ini dilakukan dengan menggunakan metode campuran (Mixed Method) memadukan pendekatan kualitatif dan kuantitatif. Mixed Method sebuah metodologi yang memberikan asumsi filosofis dalam menunjukkan arah atau memberi petunjuk cara pengumpulan data dan menganalisis data, serta perpaduan pendekatan kualitatif dan kuantitatif melalui beberapa fase proses penelitian (Sugiyono, 2013).

Pendekatan yang digunakan adalah fenomenologi, yang berupaya melihat sedalam mungkin kejadian-kejadian yang terjadi di masyarakat. Menurut Creswell (1998), studi fenomenologi menggambarkan arti sebuah pengalaman hidup untuk beberapa orang tentang sebuah konsep atau fenomena. Dengan melihat fenomena kehidupan keluarga baik secara individu maupun kelompok, serta bagaimana kehidupan itu mempengaruhi motif kehidupan manusia, tindakan, serta komunikasi mereka. Dalam melakukan penelitian ini, peneliti sebagai human instrument, berfungsi menetapkan fokus penelitian dengan bantuan alat-alat wawancara seperti kuesioner dan buku catatan.

Kuesioner dibuat sesuai dengan kebutuhan untuk analisis data, serta supaya tujuan dari penelitian tercapai. Kuesioner memuat indikator-indikator tentang: profil

responden; pengetahuan dan tindakan masyarakat terkait banjir; rencana keluarga untuk merespons kondisi darurat dan mengantisipasi banjir; peringatan/ deteksi dini banjir; dan mobilisasi sumberdaya rumah tangga.

Waktu pelaksanaan penelitian dan teknik pengambilan sampel responden sangat berpengaruh terhadap hasil yang diperoleh dalam penelitian. Penelitian ini dilakukan mulai dari 6 September - 5 November 2017. Adapun teknik pengambilan sampel responden dilakukan dengan menggunakan purposive sampling yang kemudian dilanjutkan dengan snowball sampling yang telah memenuhi kriteria. Purposive sampling dapat diartikan teknik pengambilan sampel sumber data dengan pertimbangan tertentu, sedangkan snowball sampling adalah teknik penentuan sampel yang mula-mula jumlahnya kecil, kemudian sampel tersebut 
disuruh memilih teman-temannya untuk dijadikanTabel

sampel begitu seterusnya, sehingga jumlah sampel semakin banyak (Sugiyono, 2013). Jumlah sampel responden dalam penelitian ini adalah sebanyak 60 orang.

\section{HASIL DAN PEMBAHASAN}

\subsection{Gambaran Karakteristik Demografi Wilayah dan Profil Responden}

Berdasarkan data dari BPS Kota Bekasi (2016), Kota Bekasi pada tahun 2016 memiliki karakteristik penduduk yang di dominasi oleh kelompok umur produktif, yaitu antara $25-29$ tahun. Persentase penduduk pada kelompok umur produktif tersebut adalah sebanyak 10,79 persen dari total penduduk, sedangkan penduduk pada kelompok umur 60 - 64 tahun memiliki persentase paling rendah, yaitu hanya 1,65 persen. Kondisi tersebut merupakan hal yang baik, karena kerentanan dari faktor umur penduduk termasuk rendah. Data secara lengkap dapat dilihat dalam Tabel 2 berikut ini.

Tabel 2. Data Demografi Kota Bekasi Tahun 2016

\begin{tabular}{|l|c|c|c|}
\hline Kecamatan & $\begin{array}{c}\text { Jumlah } \\
\text { (Jiwa) }\end{array}$ & $\begin{array}{c}\text { Luas } \\
\text { (ha) }\end{array}$ & $\begin{array}{c}\text { Kepadatan } \\
\text { (Jiwa/ ha) }\end{array}$ \\
\hline Pondokgede & 298.075 & 1.629 & 182,98 \\
\hline Jatisampurna & 141.479 & 1.449 & 97,64 \\
\hline Pondok Melati & 155.407 & 1.857 & 83,69 \\
\hline Jatiasih & 244.207 & 2.200 & 111,00 \\
\hline Bantargebang & 119.230 & 1.704 & 69,97 \\
\hline Mustika Jaya & 243.917 & 2.473 & 98,63 \\
\hline Bekasi Timur & 259.879 & 1.349 & 192,65 \\
\hline Rawalumbu & 256.622 & 1.567 & 163,77 \\
\hline $\begin{array}{l}\text { Bekasi } \\
\text { Selatan }\end{array}$ & 227.246 & 1.496 & 151,90 \\
\hline Bekasi Barat & 299.180 & 1.889 & 158,38 \\
\hline Medan Satria & 184.987 & 1.471 & 125,76 \\
\hline Bekasi Utara & 373.054 & 1.965 & 189,85 \\
\hline Kota Bekasi & $\mathbf{2 . 8 0 3 . 2 8 3}$ & $\mathbf{2 1 . 0 4 9}$ & $\mathbf{1 3 3 , 1 8}$ \\
\hline
\end{tabular}

Sumber: Kota Bekasi Dalam Angka (2017)

Secara administratif perumahan Pondok Gede Permai berada di Kelurahan Jatirasa, Kecamatan Jatiasih, Kota Bekasi. Berdasarkan data yang diperoleh dari Kelurahan Jatirasa diketahui bahwa perumahan Pondok Gede Permai terdiri dari lima Rukun Warga (RW). Adapun jumlah kepala keluarga (KK) dari setiap RW dapat dilihat pada Tabel 3 berikut ini.
3. Jumlah Kepala Keluarga (KK) di Perumahan Pondok Gede Permai Tahun 2016

\begin{tabular}{|c|r|r|r|r|c|}
\hline & RW 08 & RW 09 & RW 10 & RW 11 & RW 12 \\
\hline $\begin{array}{c}\text { Jumlah } \\
\text { KK }\end{array}$ & 372 & 372 & 354 & 245 & 185 \\
\hline
\end{tabular}

Sumber: Kelurahan Jatirasa (2017)

Berdasarkan informasi dari Kelurahan Jatirasa melalui wawancara mendalam dengan Lurah Jatirasa, diperoleh informasi bahwa wilayah yang sering mengalami banjir terparah di perumahan Pondok Gede Permai adalah RW 08, RW 09, dan RW 10. Hal tersebut dijadikan pertimbangan dalam melakukan pemilihan sampel responden, karena warga RW 08, RW 09, dan RW 10 lebih mempunyai pengalaman dalam menghadapi bencana banjir. Selanjutnya dengan menggunakan metode snowball sampling diperoleh sebanyak 60 responden dari ketiga RW tersebut, yang dapat mewakili populasi yang ada.

Berdasarkan penelitian yang sudah dilakukan didapatkan bahwa $61,67 \%$ responden adalah perempuan dan sisanya $38,33 \%$ adalah laki-laki. Banyaknya diperoleh responden perempuan dapat disebabkan karena waktu yang digunakan pada saat penyebaran kuesioner adalah pada hari dan jam kerja. Selain itu penggunaan metode snowball sampling juga berpengaruh, karena responden perempuan yang terpilih cenderung merekomendasikan responden yang dipilih berikutnya adalah juga perempuan.

Jika dilihat berdasarkan umur responden maka dapat diketahui umur responden terpilih berkisar antara 24 - 66 tahun, dengan persentase terbesar yaitu umur 40 - 49 tahun $(40 \%)$ dan persentase terkecil umur lebih dari 59 tahun (3,33\%). Tingkat pendidikan responden terpilih terbanyak adalah lulusan $\mathrm{S} 1 \mathrm{ke}$ atas, yaitu sebanyak 56,67\%. Pekerjaan dari responden terpilih terbanyak adalah ibu rumah tangga, dengan persentase sebesar $45 \%$. Status kepemilikan rumah dari responden terpilih mayoritas adalah 93,33\% milik sendiri dan sisanya adalah sewa/ mengontrak sebesar $6,67 \%$. Berdasarkan pengalaman mengalami kejadian banjir, sebanyak $85 \%$ responden sudah mengalami lebih dari 5 kali kejadian banjir selama tinggal di perumahan Pondok Gede Permai. 


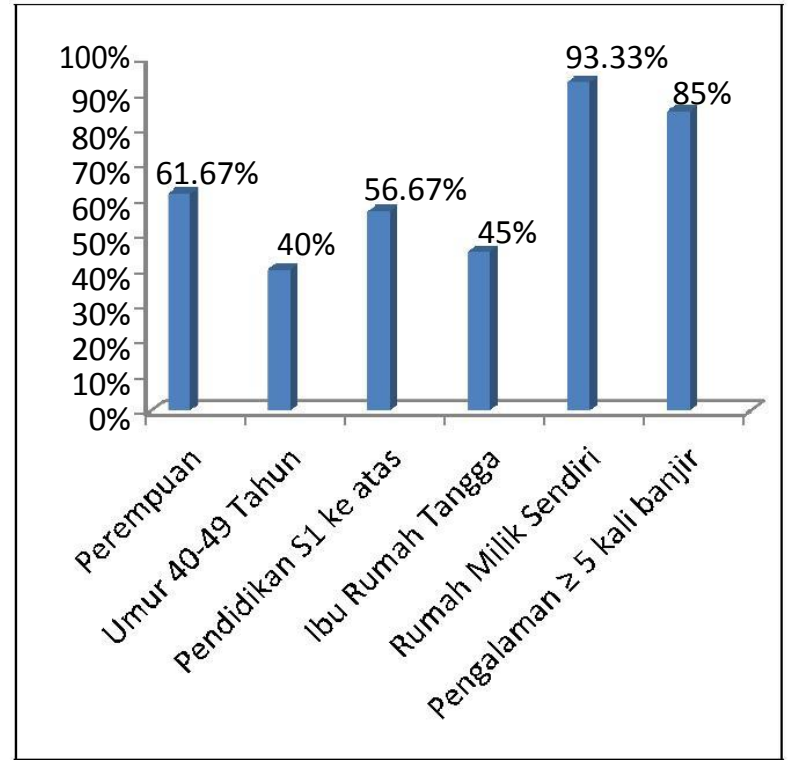

Gambar 3. Grafik Karakteristik Dominan Profil Responden

Berdasarkan hasil penelitian terhadap karakteristik responden dapat dilihat bahwa mayoritas warga perumahan Pondok Gede Permai masih berada di usia produktif, dengan tingkat pendidikan yang cukup tinggi, mereka merupakan warga yang sudah cukup lama tinggal di lokasi tersebut mengingat perumahan Pondok Gede Permai dibangun pada sekitar tahun 1990, sehingga mereka punya pengalaman yang banyak mengenai kejadian banjir. Meskipun responden didominasi oleh perempuan $(61,67 \%)$, tidak mengurangi obyektifitas dari hasil penelitian mengingat mayoritas (85\%) dari responden adalah masyarakat yang sudah cukup punya pengalaman menghadapi bencana banjir, karena sudah lebih dari 5 kali mengalami kejadian banjir di tempat tinggalnya.

\subsection{Pengetahuan dan Tindakan Masyarakat terkait Banjir}

Berdasarkan hasil penelitian yang telah dilakukan didapatkan bahwa semua responden terpilih (100\%) menyatakan bahwa kejadian banjir yang sering terjadi di lokasi tempat tinggal mereka merupakan termasuk dalam kategori bencana, karena menurut mereka banjir yang terjadi menyebabkan gangguan terhadap kehidupan masyarakat $(46,67 \%)$, banjir yang terjadi merupakan kejadian alam yang menyebabkan korban jiwa dan kerugian harta benda $(18,33 \%)$, banjir yang terjadi merupakan akibat dari pembuangan sampah yang sembarangan (25\%), dan banjir dianggap merupakan genangan air yang terjadi setelah hujan $(10 \%)$.

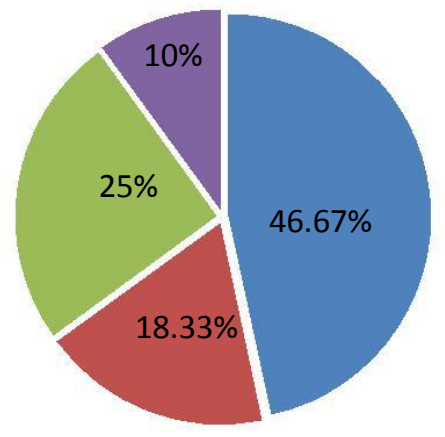

$$
\begin{aligned}
& \text { Menyebabkan gangguan lingkungan } \\
& \text { Menyebabkan kerugian harta benda \& korban jiwa } \\
& \text { Akibat buang sampah sembarangan } \\
& \text { Genangan air setelah hujan }
\end{aligned}
$$

Gambar 4. Pengertian Banjir Menurut Responden

Berdasarkan pengalaman responden terhadap kejadian bencana banjir, mereka menganggap bahwa banjir sudah mengganggu kehidupan namun masih bisa ditangani, seperti mengalami kesulitan air bersih, kesulitan bekerja, listrik mati (53,33\%), mengganggu dan sulit ditanggani, sudah menyebabkan berbagai permasalahan, seperti terpaksa tidak bekerja, harus menyelamatan keluarga dan harta benda $(31,67 \%)$, bencana atau malapetaka karena sudah tidak terkendali dan untuk keselamatan semua keluarga harus mengungsi (15\%).

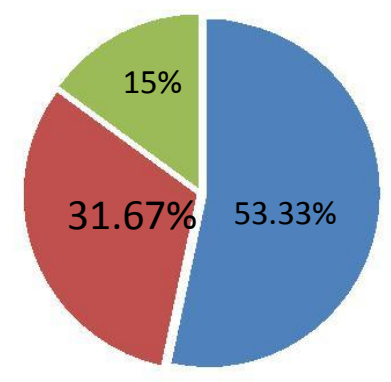

Mengganggu masih dapat ditangani
Mengganggu sulit ditangani
Malapetaka/ tidak terkendali

\section{Gambar 5. Pengalaman Banjir Responden}

Faktor-faktor penyebab terjadinya bencana banjir teridentifikasi menjadi 2, yaitu karena faktor alam dan faktor manusia. Berdasarkan pengetahuan responden faktor alam penyebab bencana banjir meliputi adanya curah hujan dengan intensitas tinggi terutama bagian di hulu 
sungai (43,33\%), adanya erosi dan sedimentasi yang menyebabkan pendangkalan sungai (30\%), kondisi tempat tinggal yang berada di cekungan/ dataran rendah $(20 \%)$, dan adanya air laut yang pasang $(6,67 \%)$. Sedangkan faktor manusia yang menyebabkan terjadinya bencana banjir menurut pengetahuan responden, perilaku buang sampah sembarangan (55\%), pembangunan rumah di bantaran sungai $(23,33 \%)$, penebangan hutan secara liar $(11,67 \%)$, pembangunan yang membuat alih fungsi lahan (10\%).

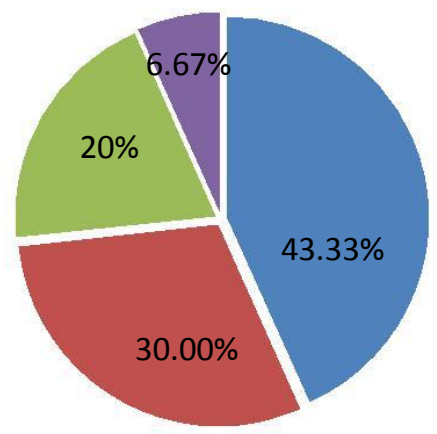

\begin{tabular}{|ll|}
\hline ॥Curah hujan & Pendangkalan sungai \\
„Dataran rendah & Air laut pasang \\
\hline
\end{tabular}

Gambar 6. Faktor Alam Penyebab Banjir

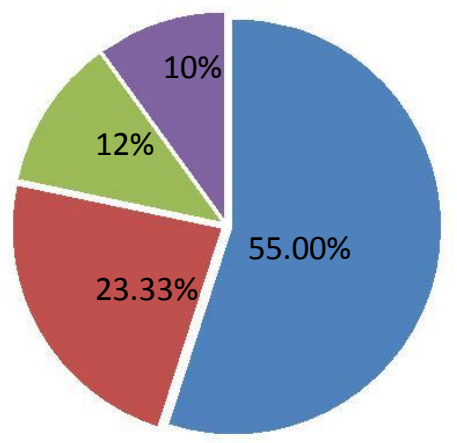

$\begin{array}{ll}\text {-Buang sampah } & \quad \text { Rumah di bantaran sungai } \\ \square \text { Penebangan hutan } & \square \text { Alih fungsi lahan }\end{array}$

Gambar 7. Faktor Manusia Penyebab Banjir

Tingkat pengetahuan masyarakat tentang tanda-tanda akan terjadinya bencana banjir dapat teridentifikasi dari setiap jawaban responden, menurut responden tanda-tanda akan terjadinya bencana banjir jika hujan lebat di wilayah hulu sungai lebih dari 2 jam (26,67\%), Ada informasi tinggi muka air di hulu melebihi ambang batas normal $(51,67 \%)$, berdasarkan informasi responden ambang batas normal Sungai Cileungsi $\geq 400 \mathrm{~mm}$ dan Sungai Cikeas $\geq$
$270 \mathrm{~mm}$. Air sungai berwarna keruh dan banyak material yang hanyut terbawa aliran air sungai $(3,33 \%)$, tanggul sungai mulai bocor atau jebol dan pompa tidak berfungsi (18,33\%).

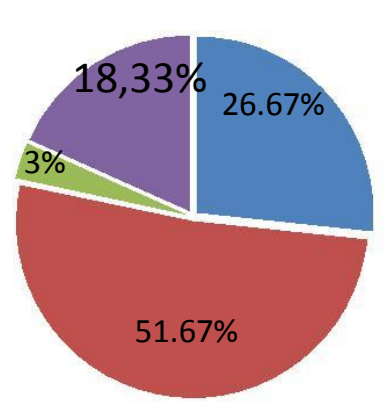

\begin{tabular}{|l|}
\hline Hujan lebat di \\
hulu $>2$ jam \\
Tinggi muka air \\
di hulu > batas \\
normal \\
Air sungai keruh \\
dan bawa \\
material \\
Tanggul \\
sungai bocor/ \\
jebol
\end{tabular}

\section{Gambar 8. Tanda-tanda akan Terjadi Banjir}

Terkait dengan tindakan yang dilakukan untuk mencegah atau mengurangi terjadinya bencana banjir, responden memiliki berbagai jawaban atas pertanyaan tersebut. Dari berbagai jawaban responden dapat menggambarkan tingkat pengetahuan masyarakat. Tindakan yang dilakukan untuk mencegah atau mengurangi terjadinya bencana banjir dengan membuang sampah pada tempatnya $(26,67 \%)$, membersihan saluran air di sekitar rumah tempat tinggal (20\%), bergotong royong membersihkan sungai $(16,67 \%)$, menanam pohon di daerah hulu $(13,33 \%)$, dan meninggikan tanggul sungai $(23,33 \%)$.

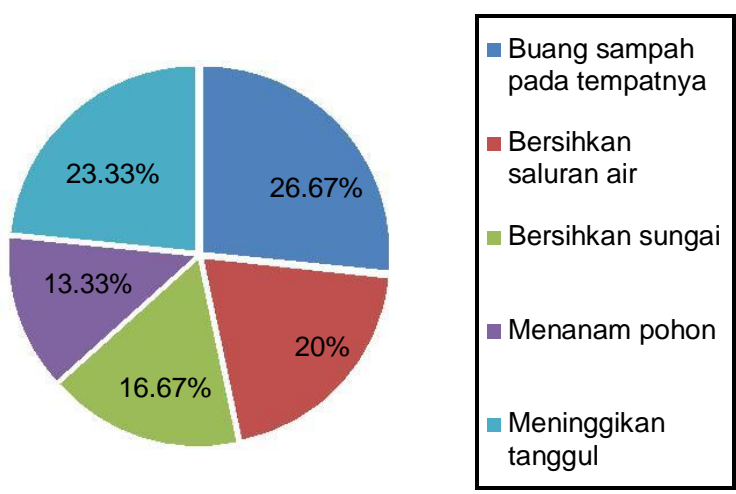

Gambar 9. Tindakan untuk Mencegah / Mengurangi Banjir

Tindakan yang dilakukan oleh masyarakat terkait kejadian bencana banjir terbagi dalam tiga tahapan, yaitu sebelum terjadi banjir, pada saat terjadi banjir, dan setelah terjadi banjir. Untuk tindakan yang dilakukan sebelum terjadi banjir, responden menyiapkan tas siaga bencana yang berisi dokumen penting/ surat berharga (3,33\%), menyiapkan logistik (bahan makanan) untuk kebutuhan darurat (10\%), menyiapkan peralatan untuk evakuasi $(21,67 \%)$, merenovasi rumah dengan meninggikan pondasi atau membangun 
rumah menjadi dua lantai (41,67\%), merencanakan/ menempatkan barang-barang berharga di tempat yang relatif aman (23,33\%).

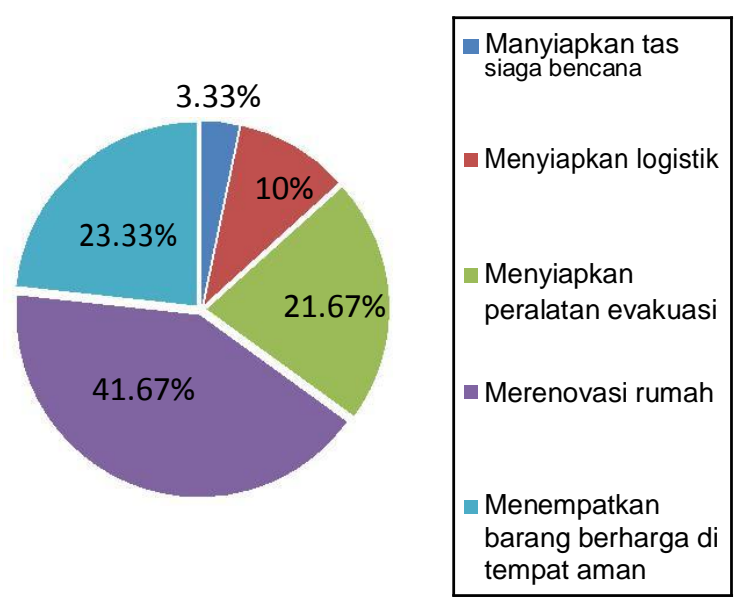

Gambar 10. Tindakan yang Dilakukan Sebelum Banjir

Tindakan yang dilakukan oleh masyarakat pada saat banjir terjadi berdasarkan informasi yang diperoleh dari responden adalah tetap di rumah untuk menjaga keselamatan barangbarang $(36,67 \%)$, mencari informasi terkait banjir melalui tetangga, handy talky, handphone, televisi, dan radio $(25 \%)$, memastikan persediaan makanan/ logistik cukup (6,67\%), memastikan semua anggota keluarga dalam keadaan aman $(20 \%)$, mengungsi ke tempat yang aman $(1,67 \%)$, dan memastikan kendaraan berada di tempat yang aman $(11,67 \%)$. Berdasarkan informasi dari responden sangat sedikit masyarakat yang mengungsi/ melakukan evakuasi atau tetap berada di rumah saat terjadi banjir, karena sebagian besar masyarakat sudah meninggikan rumahnya.

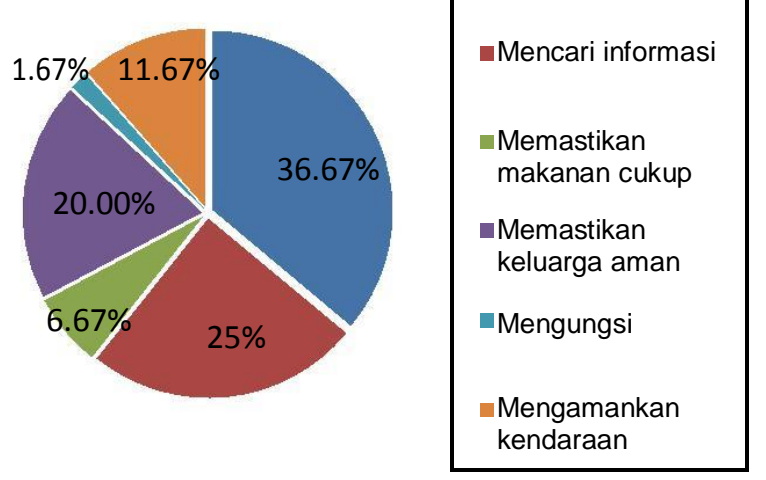

Gambar 11. Tindakan yang Dilakukan Saat Banjir

Tindakan yang dilakukan oleh masyarakat setelah terjadi banjir berdasarkan informasi yang diperoleh dari responden adalah membersihkan rumah dan barang-barang dari air/ lumpur/ sampah banjir $(58,33 \%)$, menyediakan kebutuhan air bersih dan fasilitas MCK untuk kebutuhan keluarga $(13,33 \%)$, memastikan kondisi kesehatan keluarga dari dampak banjir (8,33\%), melakukan gotong-royong untuk membersihkan lingkungan dari berbagai sampah/ lumpur banjir (15\%), dan memastikan panel-panel listrik di rumah dalam kondisi aman (5\%).

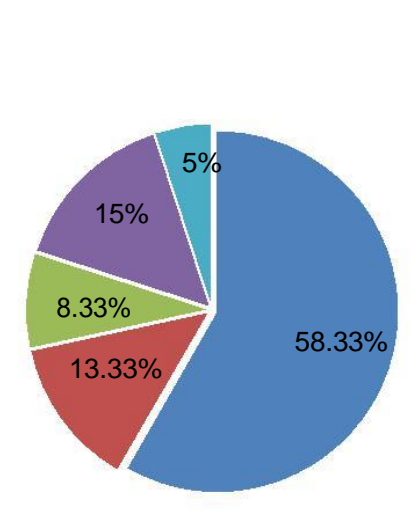

\begin{tabular}{l}
\hline Bersihkan rumah \\
- Menyediakan Air \\
bersih \\
Memastikan \\
kesehatan \\
keluarga \\
Gotong-royong \\
membersihkan \\
lingkungan \\
Memastikan panel \\
listrik aman
\end{tabular}

Gambar 12. Tindakan yang Dilakukan Setelah Banjir

Berdasarkan penelitian terhadap tingkat pengetahuan dan tindakan yang dilakukan oleh masyarakat terkait banjir sudah cukup baik, hal tersebut disebabkan karena masyarakat punya pengalaman yang banyak menghadapi bencana banjir selama tinggal di perumahan Pondok Gede Permai, serta masyarakat mau belajar dari pengalaman mereka tersebut.

\subsection{Rencana Keluarga untuk Merespons Kondisi Darurat dan Mengantisipasi Banjir}

Berdasarkan hasil penelitian yang telah dilakukan didapatkan informasi bahwa masyarakat tidak terbiasa melakukan evakuasi ketika terjadi bencana banjir. Rencana tempat evakuasi keluarga jika terjadi bencana banjir selama ini adalah rumah mereka sendiri di lantai dua $(80 \%)$, rumah saudara/ kerabat/ teman terdekat yang aman (16,67\%), dan rumah tetangga yang memiliki dua lantai $(3,33 \%)$. Masyarakat sudah terbiasa tetap berada di rumah ketika terjadi bencana banjir, mereka melakukan aktivitas ke luar rumah dalam rangka mencari informasi, bantuan logistik, atau bantuan kesehatan buat anggota keluarga. 


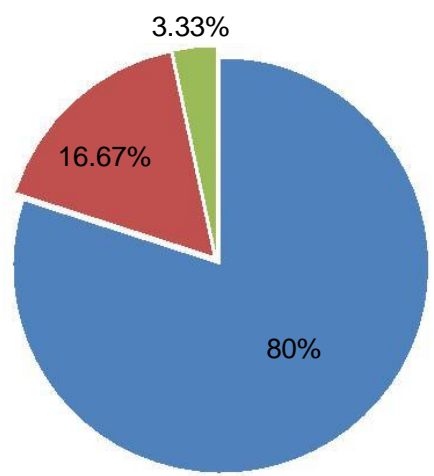

- Lantai dua $\backsim$ Rumah saudara $\backsim$ Rumah tetangga

Gambar 13. Rencana Tempat Evakuasi Keluarga

Tindakan yang dilakukan oleh keluarga dalam rangka pemenuhan kebutuhan pokok dan kebutuhan kesehatan ketika sudah mulai masuk musim penghujan dapat teridentifikasi dari jawaban responden yang bervariasi. Masyarakat menyiapkan obat-obatan untuk pertolongan pertama di rumah (30\%), menyiapkan perlengkapan untuk menyelamatkan diri/ kondisi darurat $(21,67 \%)$, menyiapkan stok bahan makanan yang cukup untuk bertahan selama banjir $(36,67 \%)$, menyiapkan alat komunikasi alternatif, seperti handytalky (5\%), menyiapkan alamat/ nomor telepon penting di rumah $(6,67 \%)$. Berdasarkan jawaban responden terbanyak adalah menyiapkan bahan makanan untuk kebutuhan selama bencana banjir terjadi, karena berdasarkan pengalaman mereka bantuan logistik ketika banjir datangnya tidak menentu, bahkan ada bantuan-bantuan yang distribusinya kurang tepat sasaran.

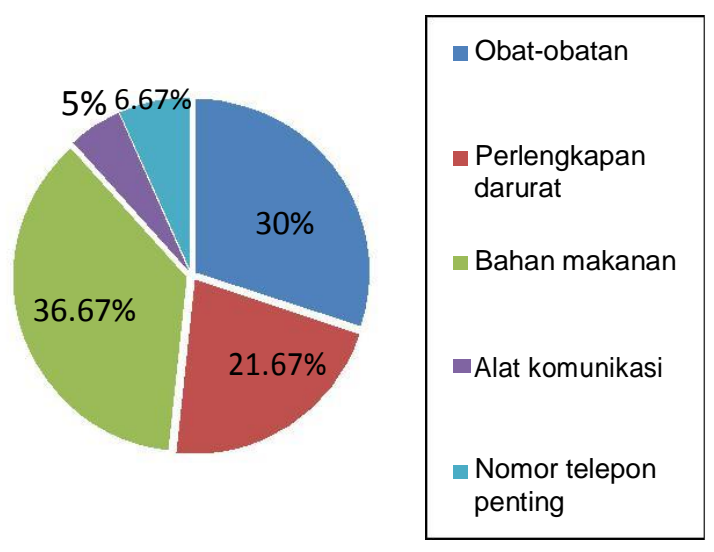

Gambar 14. Tindakan Persiapan Ketika Musim Hujan

Rencana keluarga untuk merespons kondisi darurat dan mengantisipasi banjir di perumahan Pondok Gede Permai sudah cukup baik, meskipun masih perlu ada beberapa hal yang perlu ditingkatkan, seperti rencana tanggap darurat jika terjadi bencana banjir yang sebagian besar belum dimiliki oleh setiap keluarga. Dengan kata lain, kesepakatan-kesepakatan yang dibuat di dalam anggota keluarga jika bencana banjir terjadi belum ditetapkan. Bencana banjir datang bisa kapan saja, sehingga perlu rencana tanggap darurat untuk level masing-masing keluarga.

\subsection{Peringatan/ Deteksi Dini Banjir}

Terkait dengan peringatan/ deteksi dini banjir di wilayah perumahan Pondok Gede Permai, masyarakat sangat mengandalkan informasi dari komunitas kebencanaan yang ada di wilayah mereka, seperti Komunitas Peduli Cileungsi Cikeas (KP2C) dan Kompi 887. Media penyebaran informasi yang digunakan oleh komunitas tersebut adalah melalui WhatsApp

grup dan telegram. Informasi yang disebarluaskan ke masyarakat adalah mengenai informasi tinggi muka air kondisi cuaca di hulu Sungai Cileungsi dan Sungai Cikeas. Komunitas tersebut menempatkan petugas di hulu kedua sungai tersebut, untuk memantau ketinggian muka air dan kondisi cuaca serta melaporkan melalui media WhatsApp atau telegram setiap interval tertentu sesuai dengan kondisi ketinggian muka air dan cuaca di hulu. Semakin tinggi (mendekati nilai ambang batas normal) muka air sungai, maka petugas semakin sering melaporkan hasil pemantauannya.

Berdasarkan hasil penelitian yang dilakukan, sumber peringatan dini bencana banjir yang diperoleh warga masyarakat terdiri dari informasi melalui media komunikasi komunitas, seperti WhatsApp grup dan telegram (53,33\%), untuk warga masyarakat yang tidak tergabung dalam komunitas tersebut mereka memperoleh informasi dari pengumuman yang disampaikan melalui speaker masjid/ mushola $(26,67 \%)$, ada juga yang memperoleh informasi dari tetangga/ warga sekitar tempat tinggalnya $(8,33 \%)$, serta dari bunyi-bunyian seperti kentongan atau tiang listrik yang dipukul $(11,67 \%)$. Dari data tersebut dapat terlihat bahwa sudah banyak warga masyarakat perumahan Pondok Gede Permai yang tergabung dalam anggota komunitas, baik KP2C maupun Kompi 887. Hal tersebut terlihat dari angka $53,33 \%$ masyarakat yang memperoleh informasi peringatan dini banjir dari media komunikasi komunitas. 


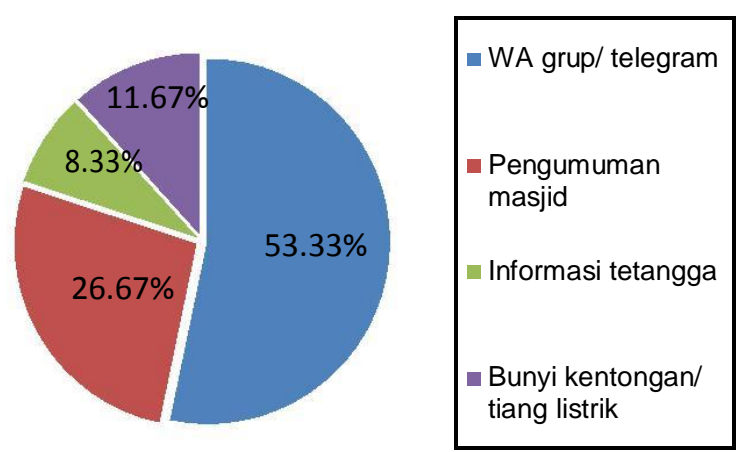

Gambar 15. Sumber Informasi Peringatan Banjir

\subsection{Mobilisasi Sumberdaya Rumah Tangga}

Berdasarkan hasil penelitian yang dilakukan menunjukkan bahwa mobilisasi sumberdaya rumah tangga masih tergolong redah, yang terlihat dari proporsi responden yang pernah mengikuti berbagai kegiatan kesiapsiaagaan bencana banjir. Berdasarkan informasi dari responden hal tersebut terjadi karena sangat jarang sekali diadakannya kegiatan terkait kesiapsiaagaan bencana banjir di lingkungan perumahan Pondok Gede Permai. Dari indikator yang digunakan untuk mobilisasi sumberdaya rumah tangga dalam bencana banjir yang berupa keikutsertaan masyarakat dalam kegiatan kesiapsiaagaan bencana banjir diperoleh data bahwa masyarakat yang sudah pernah mengikuti pelatihan atau pertemuan yang berkaitan dengan kesiapsiagaan masyarakat dalam menghadapi bencana banjir $(13,33 \%)$, dan sisanya belum pernah mengikuti kegiatan kesiapsiaagaan bencana banjir $(86,67 \%)$.

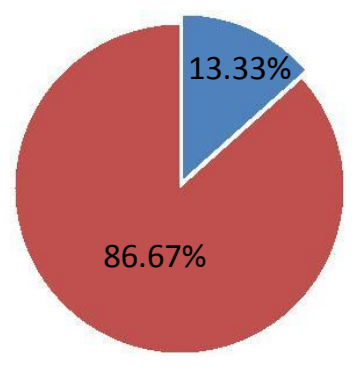

- Sudah pernah

Belum pernah

Gambar 16. Keikutsertaan Masyarakat dalam Kegiatan Kesiapsiagaan Banjir

Dalam rangka mengamankan aset dan investasi yang dimiliki warga masyarakat untuk kesiapsiagaan mengantisipasi terjadinya bencana banjir, beberapa hal dapat dipersiapkan antara lain dengan menyiapkan tabungan (15\%), mengikuti asuransi jiwa/ harta/ benda $(28,33 \%)$, investasi rumah/ tempat tinggal di lokasi lain (5\%), ada pula yang tidak sama sekali $(51,67 \%)$. Masih rendahnya upaya

masyarakat untuk investasi dalam rangka kesiapsiagaan banjir, dapat disebabkan oleh faktor masih kurangnya tingkat kesadaran masyarakat untuk investasi dalam rangka kesiapsiagaan menghadapi banjir, namun disisi lain juga dapat terkait dengan tingkat kesejahteraan masing-masing warga.

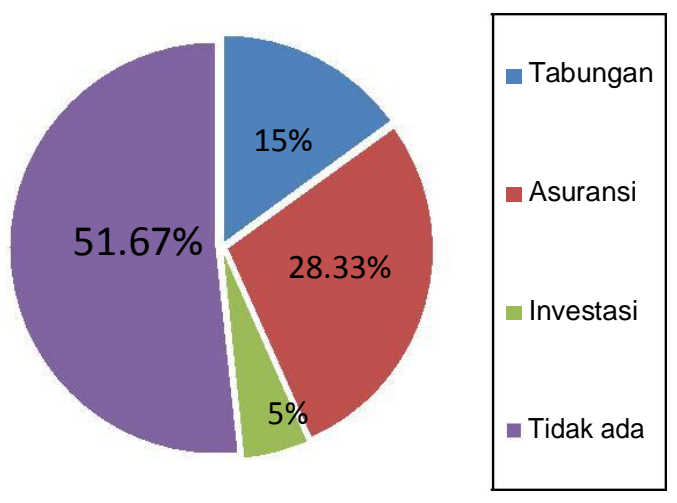

Gambar 17. Upaya Mengamankan Aset dan Investasi dalam Rangka Mengantisipasi Banjir

Warga masyarakat perumahan Pondok Gede Permai sebagian besar adalah warga pendatang dari luar daerah. Mereka merasa sudah nyaman tinggal di lokasi tersebut walaupun harus menghadapi ancaman bahaya banjir ketika musim penghujan datang. Faktor utama yang membuat mereka nyaman tinggal di lokasi tersebut adalah karena hubungan persaudaraan yang sudah terjalin dengan baik antar sesama warga perumahan Pondok Gede Permai. Terkait kewaspadaan terhadap bencana banjir responden memilih untuk tetap tinggal di lokasi tersebut $(81,67 \%)$, dan sebagian kecil berkeinginan untuk pindah tempat tinggal ke lokasi lain (18,33\%).

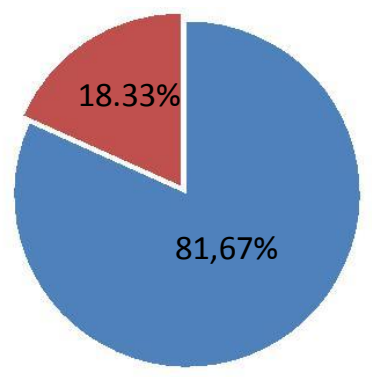

घ Tetap tinggal $\quad$ Pindah lokasi lain

Gambar 18. Keinginan untuk Pindah Tempat Tinggal 


\section{KESIMPULAN}

Berdasarkan hasil penelitian yang sudah dilakukan, maka dapat disimpulkan beberapa hal sebagai berikut:

1. Karakteristik demografi wilayah di Kota Bekasi mayoritas penduduknya berada di usia produktif (antara 25 - 29 tahun) sebanyak 10, $79 \%$, sedangkan profil responden didominasi oleh perempuan $(61,67 \%)$, umur 40 - 49 tahun (40\%), pendidikan S1 ke atas $(56,67 \%)$, ibu rumah tangga (45\%), statusnya pemilik rumah $(93,33 \%)$, dan sudah lebih dari 5 kali mengalami kejadian banjir (85\%).

2. Tingkat pengetahuan dan tindakan masyarakat terkait banjir cukup baik, karena masyarakat memiliki pengalaman banyak menghadapi bencana banjir selama tinggal di lokasi tersebut, serta masyarakat mau belajar dari pengalaman tersebut. Indikator yang menunjukkan tingkat pengetahuan masyarakat cukup baik antara lain, 100\% responden mengkategorikan banjir sebagai bencana, 55\% responden menganggap faktor manusia yang menyebabkan banjir adalah buang sampah di sungai, 43,33\% responden---menganggap faktor alam yang menyebabkan banjir adalah curah hujan yang tinggi, dar-, $51,67 \%$ responden berpendapat tanda-tanda akan terjadinya banjir adalah tinggi muka air di hulu yang melebihi abang batas normal.

3. Rencana keluarga untuk merespons kondisi darurat dan mengantisipasi banjir cukup baik, hal tersebut dapat dilihat dari $80 \%$ responden sudah mempersiapkan tempat evakuasi dengan lokasi lantai 2 di rumah mereka masing-masing. Namun demikian masih ada beberapa hal yang perlu ditingkatkan, seperti rencana tanggap darurat jika terjadi bencana banjir yang sebagian besar belum dimiliki oleh setiap keluarga.

4. Peringatan/ deteksi dini banjir masyarakat mengandalkan informasi yang diperoleh dari komunitas melalui WhatsApp grup atau telegram sebanyak $53,33 \%$ responden. Informasi berisikan tinggi muka air Sungai Cileungsi dan Sungai Cikeas di bagian hulu berikut dengan informasi kondisi cuaca.

5. Mobilisasi sumberdaya rumah tangga masih cukup rendah, hal tersebut terlihat dari indikator minimnya keikutsertaan masyarakat dalam kegiatan kesiapsiagaan menghadapi bencana banjir (13,33\%). Sehingga perlu ada upaya dari pihak-pihak terkait untuk menyelenggarakan kegiatan di lokasi tersebut dalamrangkauntukmeningkatkan kesiapsiagaan masyarakat menghadapi bencana banjir.

\section{DAFTAR PUSTAKA}

Aryono, D.P. 2011. The Silent Disaster Bencana dan Korban Massal. CV. Sagung Seto. Jakarta.

Badan Pengkajian dan Penerapan Teknologi. 2017. Pembangunan Sistem Monitoring Peringatan Dini Banjir (FEWS, Laporan, tidak dipublikasikan).

Badan Perencanaan Pembangunan Daerah Kota Bekasi. 2017. Masterplan Drainase (Sisi Timur Kali Bekasi). PT. Arenco Binatama. Bekasi.

Badan Pusat Statistik Kota Bekasi. 2017. Kota Bekasi Dalam Angka 2016. Bekasi.

Creswell. 1998. Qualitative Inquiry: Choosing Among Five Traditions. Sage Publications.

Daryono. 2010. Mitigasi Bencana Banjir (Online) http://www.sumeks.co.id.

Nazir, M. 1983. Metode Penelitian. Ghalia Indonesia. Bogor.

Sugiyono, 2013. Metode Penelitian Kuantitatif, Kualitatif dan R\&D. Bandung. CV. Alfabeta.

http://dibi.bnpb.go.id Diakses pada 19 Desember 2017.

www.bbc.com/indonesia Diakses pada 20 Desember 2017. 